\title{
UNIONISM AND THE DISPERSION OF WAGES
}

\author{
RICHARD B. FREEMAN*
}

\begin{abstract}
This study examines the effect of trade unionism on the dispersion of wages among male wage and salary workers in the private sector in the United States. It finds that the application of union wage policies designed to standardize rates within and across establishments significantly reduces wage dispersion among workers covered by union contracts and that unions further reduce wage dispersion by narrowing the white-collar/blue-collar differential within establishments. These effects dominate the more widely studied impact of unionism on the dispersion of average wages across industries, so that on net unionism appears to reduce rather than increase wage dispersion or inequality in the United States.
\end{abstract}

$\mathrm{T}$ RADE unionism alters the distribution of wages in several ways. First, by raising the wages of organized workers relative to others, unionism changes the dispersion of wages in the economy, increasing inequality when highly paid workers are organized and reducing inequality when low-paid workers are organized. On the basis of estimates of the wage effect and its correlation with wage levels, Lewis concluded that by raising wages unionism has raised the relative inequality of average wages among industries, as measured by the standard deviation of relative wages, by two to three percentage points. ${ }^{1}$ In addition, simply by creating differentials between otherwise comparable workers (regardless of their level of

- Richard Freeman is a professor of economics at Harvard University. He has benefitted from the research assistance of Casey Ichniowski.

${ }^{1} \mathrm{H}$. Gregg Lewis, Unionism and Relative Wages in the United States: An Empirical Inquiry (Chicago: University of Chicago Press, 1963), p. 282. pay), unionism also increases inequality. Alternately, however, unions also affect the dispersion of wages within the organized sector through the "standard rate" policies stressed in the institutional literature. ${ }^{2}$ While most economists accept the notion that standardization of rates reduces dispersion among union members, quantitative estimates of this effect are lacking. The within-sector effect could be large, offsetting or more than offsetting the increase in inequality due to the impact on dispersion across groups, or it could be small.

\footnotetext{
${ }^{2}$ Lloyd G. Reynolds and Cynthia H. Taft, The Evolution of Wage Structure (New Haven, Conn.: Yale University Press, 1956); Sumner H. Slichter, James J. Healy, and E. Robert Livernash, The Impact of Collective Bargaining on Management (Washington, D.C.: The Brookings Institution, 1960). Sidney and Beatrice Webb, Industrial Democracy (London: Longmans, Green and Co., 1902). David A. McCabe, The Standard Rate in American Trade Unions (Baltimore, Md.: The Johns Hopkins Press, 1912).
} 
The purpose of this paper is to estimate the magnitude of the effect of unionism on the dispersion of wages in the organized sector and to use the estimates to examine the potential contribution of the institution to overall wage dispersion. The first section of the paper reviews the evidence on trade union standard rate policies and considers the economic rationale underlying them. The second section contrasts the dispersion of earnings among blue-collar workers in the organized sector with that in the unorganized sector. Section three examines the effect of unionism on the differential between production and nonproduction workers within establishments. Section four then compares the dispersion-increasing and dispersion-reducing effects of unionism to obtain an estimate of the overall effect of the institution on wage inequality. A final section reports conclusions.

\section{Union Wage Policy and- Intrasectoral Dispersion}

Unionism is expected to reduce the dispersion of wages among organized workers because of long-standing union wage policies in favor of the "standard rate," defined as uniform piece or time rates among comparable workers across establishments and impersonal rates or ranges of rates in a given occupational class within establishments.

That unions strive to standardize rates across establishments has long been recognized by institutional labor economists. Indeed, according to Slichter, Healy and Livernash, "wage standardization within an industry or local product market is the most widely heralded union wage policy."3 Sufficient examples exist of major collective bargaining agreements that achieved standardization of rates to suggest, moreover, that the goal of uniformity across firms has influenced the wage structure. The development of the Comprehensive Wage Study in steel in 1946-47 appears to have increased uniformity among plants in that industry. ${ }^{4}$ Successive steel contracts from

\footnotetext{
'Slichter, Healy, and Livernash, The Impact of Collective Bargaining, p. 606.

'Jack Stieber, The Steel Industry Wage Structure (Cambridge, Mass.: Harvard University Press, 1959).
}

1947 to 1954 eliminated the longstanding southern "Birmingham" geographic differential. The ILGWU and Amalgamated Clothing Workers have established uniform piece rates in their contracts in broad geographic areas. The Teamsters reduced regional differentials for over-the-road drivers in 1964 when the National Master Freight Agreement was signed. In most instances of multi-employer bargaining (which in 1974 constituted 42 percent of major collective agreements in the United States), or multiplant bargaining (an additional 42 percent $t^{5}$ ), uniform or near uniform rates are established across firms.

The policy of standardization of rates across plants has not been adhered to blindly, of course. "Exceptions" are often granted to take account of specific competitive situations, such as the danger of a plant closing, ${ }^{6}$ and the relevant sector or wage "contour" for standardization changes as market conditions change. There is no denying, however, that union policies operate toward uniformity of rates among similar plants and less dispersion within the organized sector.

The economic rationale and strength of policies toward standardization of rates across establishments will depend on market conditions. When firms compete in the same market, both employer and worker interest can be expected to favor standard rates. On the firm side, no enterprise wants union contracts that are more expensive than those of its competitors. ${ }^{7}$ On the worker side, as long as markets cannot be differentiated to permit price discrimina-

${ }^{5}$ U.S. Department of Labor, Bureau of Labor Statistics, Characteristics of Major Collective Bargaining Agreements (Washington, D.C.: G.P.O., July 1, 1974), Table 18 , p. 11 .

${ }^{6}$ David H. Greenberg, "Deviations from WageFringe Standards," Industrial and Labor Relations Review, Vol. 22, No. 2 (January 1968), pp. 197-209. Morris. A. Horowitz, The New York Hotel Industry: A Labor Relations Study (Cambridge, Mass.: Harvard University Press, 1960), pp. 165-66. Kenneth Alexander, "Market Practices and Collective Bargaining in Automotive Parts," Joumal of Political Economy, Vol. 69, No. 1 (February 1961), pp. 15-29.

7Thomas Kennedy, The Significance of Wage Uniformity (Philadelphia: University of Pennsylvania Press, 1949), p. 2. 
tion, the desire for a single rate makes good sense in terms of collective behavior. Without a common rate across firms competing in the same market, the monopol istic price would come under severe pressures in economic downturns when some union members could be expected to undercut others. Uniformity across firms "takes wages out of competition."

When market conditions differ among firms, so that price discrimination by the union is possible, the desire for standardization of rates is weaker. Even here, however, the amalgamation of locals into a single national and the lack of adequate internal redistributive mechanisms within the union limits the extent of price discrimination. Union solidarity is difficult to maintain if some workers are paid markedly more than others, and such a pattern invites division within the organization and loss of certain common advantages, such as joint strike funds and interrelated policies toward major employers. Policing an agreement to maintain monopolistic rates is also likely to be difficult in this case. On the employer side, firms in low-wage local markets have often fought standardization of rates on the grounds that standardization deprives them of the advantage of lower cost. Despite some opposition to standard rates from high-wage union locals ${ }^{8}$ and low-wage firms and the granting of exceptions (which can be viewed as a step toward price discrimination), however, the overall pressures appear to operate toward standardization of rates. The balance struck between standardizing rates and granting exceptions will be influenced by such factors as market conditions, union coverage, and elasticities of demand.

The second major component of union standardization policies is for equalization of pay and reduction of "personal differences" among similarly skilled workers within establishments. Prior to unionization many industries are plagued by what have been called "inequity" problems, with different wages paid to individuals depending not on the jobs held but on the workers'

\footnotetext{
'See, for example. McCabe, The Standard Rate in American Trade Unions.
}

characteristics as perceived by foremen. Under unionism, however, the process of wage-setting within firms is quite different, with job rates rather than personal rates the major determinant of pay. The number of job categories is often relatively small (only 36 classifications in steel, for example), gathering diverse activities in single categories and thus narrowing the potential dispersion; and the range of rates within job categories tends to be narrow. While many large nonunion enterprises employ similar formal wage-setting practices today, the option for personal differentials based on ability (or favoritism, or any other factor) within a job category is generally larger than in the union sector. Merit increases appear, for example, to be less prevalent in the union than nonunion sector. In the 1970s, 43 percent of companies gave plant employees "wage adjustments based on a merit plan," 9 whereas just 12.5 percent of major union contracts had merit progression plans. ${ }^{10}$ Overall, according to Slichter, Healy, and Livernash, "the influence of unions has clearly been one of minimizing and eliminating judgement-based differences in pay for individuals employed on the same job" and of "removing ability and performance judgements as a factor in individual pay for job performance." 11

Several factors appear to explain union policies favoring reduction of within-establishment wage variation. Within a union, when the mean wage exceeds the median, a majority of members can presumably be expected to favor redistribution in favor of the lower paid. In a simple median voter model of union behavior, the $50+$ percent of members who earn less than the mean would favor a policy of greater gains for the lower paid. Union opposition to personal rates probably also reflects worker solidarity and preference for objective standards as opposed to the subjective decisions of foremen.

\footnotetext{
${ }^{9}$ Bureau of National Affairs, Wage and Salary $A d$ ministration Survey, Bulletin 97 (Washington, D.C.: G.P.O., July 1972), Table 7. p. 14.

${ }^{10}$ U.S. Department of Labor, Bureau of Labor Statistics, Characteristics of Major Collective Bargaining Agreements (July 1, 1974).

"Slichter. Healy, and Livernash, The Impact of Collective Bargaining, p. 602.
} 
It is difficult to see how the union would be able to maintain its organizational strength and monopolistic prices, in fact, with significant personal differentials within firms. Moreover, since presumably all workers obtain higher wages in the presence of the union, there are no "losers" from the policy but simply differential gainers.

Not all union wage policies, it should be noted, operate toward reduction of dispersion. The effect of unionism on blue-collar occupational differentials is unclear, ap parently varying by the type of union and workers organized. Craft unions may widen the wage structure by raising the pay of the highly skilled. Industrial unions, previously expected to reduce differentials by negotiating constant cents per hour increases, in recent years have sometimes operated to maintain or increase percentage skill differentials in response to pressures from skilled workers. After reviewing the evidence, Reynolds and Taft concluded that "any net effect on occupational differentials ... [is] in the direction of narrowing."12 Whatever unions do to the skill differential among blue-collar workers, however, they tend to raise the pay of production workers relative to higher paid nonproduction workers within firms and thus narrow that component of occupational wage differentials.

Finally, note that standardization of piece rates, as opposed to time rates, has no clear effect on dispersion. If in the absence of unionism piece rates would be higher in less productive plants, standardization would increase dispersion in hourly pay; if, conversely, piece rates would be higher in more productive plants, standardization would decrease dispersion.

These complications notwithstanding, the institutional evidence of wage policies under collective bargaining suggests that trade unionism can be expected to reduce inequality of wages within the union sector, largely by equalizing rates across establishments and by replacing personal rates by formal job rates within establishments. The key issue addressed in this paper is the mag-

\footnotetext{
${ }^{12}$ Reynolds and Taft, The Evolution of Wage Structure, p. 185.
}

nitude of this reduction. Do unions reduce inequality in wage dispersion within the union sector by a sizeable amount? And how does this reduction compare to the increase in inequality due to the potential increase in dispersion of wages between the union and nonunion sectors?

\section{Dispersion Among Blue-Collar Workers}

To evaluate the quantitative impact of standardization policies on workers in the union sector, this section compares the dispersion of wages among otherwise similar organized and unorganized blue-collar workers, using data from the Current Population Survey and Expenditures for Employee Compensation survey. Dispersion is measured by the standard deviation of the $\mathrm{ln}$ of earnings, an appropriate metric when earnings are set by the ln earnings function widely used in modern labor economics; when union wage differentials are measured in relative rather than absolute terms; and when earnings are lognormally distributed. In comparison to other widely used measures of wage dispersion, the standard deviation of $\ln$ wages weights inequality more heavily at the lower end of the distribution than at the upper end. ${ }^{13}$ Since this will attach less significance to the narrowing of the white-collar/blue-collar gap in the upper part of the distribution than to potential increased inequality between union and nonunion blue-collar workers in the lower part, the standard deviation of $\ln$ metric is likely to "understate" the equalization of wages under unionism relative to other widely used metrics (such as Gini coefficients, for example).

The principal problem in comparing dispersion of wages between organized and unorganized blue-collar or production workers is to differentiate between the effect of unionism and the effect of other factors correlated (for whatever reason) with unionism. If union workers were more alike in personal characteristics or in their distributions among industries or occupations than

\footnotetext{
${ }^{13}$ For a discussion of the properties of diverse measures of inequality see Anthony $\mathbf{B}$. Atkinson, "On the Measurement of Inequality," Journal of Economic Theory, Vol. 9, No. 1 (1970), pp. 244-63.
} 
nonunion workers, the variance in $\ln$ wages would be lower in the union sector for reasons extraneous to standardization policies.

This study employs several techniques to deal with this problem. One is to compare dispersion within narrowly defined groups, such as workers in the same three-digit industry with the same age, sex, and education. As comparison cells become increasingly narrow, the possibility of differences due to omitted factors that are correlated with unionism is reduced.

Multiple regression analysis provides another tool for "correcting" for the effect of different characteristics and identifying those due to union wage policies. Let $X_{i}$ be a determinant of $1 \mathrm{n}$ wages $(W), \hat{b}_{i}$ be its coefficient, and $\hat{e}$ be the residual. Then, with the superscript $u$ for union workers and $n$ for nonunion workers, we have union and nonunion wage equations:

$$
\begin{gathered}
W^{u}=\hat{a}^{u}+\sum_{i} \hat{b}_{i}^{u} X^{u}+\hat{e}_{i}^{u} \text { and } \\
W^{n}=\hat{a}^{n}+\sum_{i} \hat{b}_{i}^{n} X^{n}+\hat{e}_{i}^{n} .
\end{gathered}
$$

The regression decomposes the variance in $W^{u}$ and $W^{n}$ into a part explained by the wage determinants and a residual.

Next, if union workers have different characteristics than nonunion workers, the variance and covariance of the $X$ s will differ between the two groups, with resultant differences in the variances of $W^{u}$ and $W^{n}$. Variance decomposition of the equations will be used to eliminate the effect of differences in characteristics by estimating the impact of different dispersions of the Xs on the dispersion of earnings, given either the union or nonunion regression weights. For example, the extent to which $\sigma^{2}\left(W^{u}\right)$ differs from $\sigma^{2}\left(W^{n}\right)$ as a result of differences in the characteristics in the samples can be gauged by: ${ }^{14}$

$$
\begin{gathered}
\sum_{i}\left(\hat{b}_{i}\right)^{2}\left[\sigma^{2}\left(X_{i}^{u}\right)-\sigma^{2}\left(X_{i}^{n}\right)\right] \\
+\sum_{i} \sum_{j} \hat{b}_{i} \hat{b}_{j}\left[\sigma\left(X_{i}^{u} X_{j}^{u}\right)-\sigma\left(X_{i}^{n} X_{j}^{n}\right)\right]
\end{gathered}
$$

\footnotetext{
${ }^{14}$ The two variances differ only by the regression coefficients and thus represent the approximate standardization for differences in characteristics. This is not, of course, a complete decomposition.
}

where $\sigma^{2}\left(X_{i}^{u}\right)$ is the variance in characteristic $i$ among union members; $\sigma\left(X_{i}^{u} X_{j}^{u}\right)$ is the covariance in characteristics among union members and $\sigma^{2}\left(X_{i}^{n}\right)$ and $\sigma^{2}\left(X_{i}^{n} X_{j}^{n}\right)$ are the relevant variances and covariances for nonunion workers and where $\hat{b}$ s can be taken from either the union or nonunion regressions. Any variation not attributable to Equation 3 represents the effect of unionism on dispersion among similar workers.

The decomposition of differences in dispersion can be pursued further by comparing the variance explained by the regressions, conditional on similar characteristics, to the residual variation. With variances and covariances of the $X s$ fixed, unionism can change dispersion by altering the effect of wage-determining variables on earnings, reducing (or increasing) the regression coefficient in earnings equations; or by altering the dispersion of earnings among workers with the same wage-determining characteristics. The first effect can be estimated by comparing the dispersion of wages of a group of workers with given characteristics that would result from Equation 1 , the union wage equation, with dispersion that would result from Equation 2, the nonunion wage equation:

$$
\begin{gathered}
\sum_{i}\left[\left(\hat{b}_{i}^{n}\right)^{2}-\left(\hat{b}_{i}^{u}\right)^{2}\right] \sigma^{2}\left(X_{i}\right) \\
+\sum_{i} \sum_{j}\left(\hat{b}_{i}^{n} \hat{b}_{j}^{n}-\hat{b}_{i}^{u} \hat{b}_{j}^{u}\right) \sigma\left(X_{i} X_{j}\right)
\end{gathered}
$$

where $\sigma^{2}\left(X_{i}\right)$ and $\sigma\left(X_{i} X_{j}\right)$ refer to the dispersion of characteristics among either union or nonunion workers.

Differences in the residual variances themselves, as reflected in the standard errors of estimates of the equations ( $\hat{\sigma}=$ $\Sigma \sqrt{\hat{e}^{2} / N}$ where $N=$ degrees of freedom), provide one possible measure of the impact of unionism on the wages of workers with identical characteristics within the separate sectors. The residual variances reflect the variation remaining after the coefficients and variances and covariances of independent variables in the union equation and in the nonunion equation have been taken account of in the separate regressions.

Finally, since the sum of squares due to the regression and the sum of squared re- 
siduals in each equation are independent, differences between the various variances can be tested by the standard F statistics with degrees of freedom dependent on the observations and number of control variables in the regressions: $\mathrm{F}=\left(\hat{\sigma}^{u} / \hat{\sigma}^{n}\right)^{2} \mathrm{f} u r$ the residual variation and $\mathrm{F}=R_{n}^{2} \hat{\boldsymbol{\sigma}}^{2}\left(W^{n}\right) / R_{u}^{2}$ $\hat{\boldsymbol{\sigma}}^{2}\left(W^{u}\right)$ for the explained variation.

Current Population Survey data set. Estimates of the dispersion of wages among union and nonunion blue-collar workers and of the contributions of differences in characteristics, differences in the coefficients in wage equations, and of residual variance to differences in dispersion were made using the Current Population Surveys (CPS) of the U.S. Bureau of the Census for May 1973, May 1974, and May $1975 . .^{15}$ The May surveys of the CPS contain data on union membership, usual weekly earnings, usual hours worked, and other characteristics of workers that permit analysis of differences in dispersion in relatively narrow groupings. To obtain a large sample, the three surveys were amalgamated into a single sample, with earnings in 1974 and 1975 deflated to 1973 levels to maintain comparability. To reduce differences in the characteristirs of workers, the analysis focuses on male private wage and salary workers, exclusive of students, and treats manufacturing and the rest of the economy separately.

The overall dispersion of wages among union and nonunion blue-collar workers in the sample is summarized in Table $l$ in terms of the standard deviation in usual hourly and weekly earnings for manufacturing and nonmanufacturing, respectively; the difference in standard deviations; and the $\mathbf{F}$ test for the difference. While lack of controls makes interpretation of the results subject to question, the pattern is clear: in both manufacturing and nonmanufactur-

\footnotetext{
${ }^{15}$ The Current. Population Survey is a monthly survey of about 50,000 households. The May Survey asks questions about usual weekly earnings and unionism that provide, perhaps, the best data available on dispersion of wages differentiated by union status. See the U.S. Department of Labor, Special Labor Force Report, Bulletin 195, for a detailed discussion of the earnings data.
}

ing, the dispersion of wages among unionized male blue-collar workers is considerably lower than among nonunion workers. The differences in standard deviations range from -.10 to -.14 or from 22 to 30 percent of the standard deviation in the nonunion sector. By the $\mathrm{F}$ test, all of the differences in the table are significant at better than the one percent level.

The distribution of $\ln$ wages in the two sectors themselves is examined in the figure, which presents the frequency distribution of In usual hourly earnings for union and nonunion workers. The figure permits some evaluation of the possibility that wages are less dispersed among unionists largely because of some "peculiarity" in the tails of the distribution, such as the absence of either very low or very highly paid workers from the union sector. ${ }^{16}$ The figure shows no striking aberrations in the distributions. In both manufacturing and nonmanufacturing, the upper and lower parts of the earnings distribution are more compressed about the median in the union sector, resulting in more "peaked" frequencies. Measured by the percentage difference between quintiles and the median, the top quintile is twice as far above the median in the nonunion than in the union distribution in both manufacturing and nonmanufacturing while the bottom quintile is twice as far below the median in the nonunion than union distribution in nonmanufacturing and 60 percent further below in manufacturing. Overall, the difference between the top and bottom quintiles is markedly less in union distributions, with in differences in manufacturing of .519 (nonunion) and .298 (union) and differences in nonmanufacturing of .653 (nonunion) and .326 (union). ${ }^{17}$

\footnotetext{
${ }^{16}$ This would occur if either low wage firms were driven out of the unorganized sector by union wage gains or if high wage workers eschewed unionism because of standardization policies.

${ }^{17}$ The precise quintile deviations of the distributions of $\log$ wages were: percentage deviation of the first quintile from median: manufacturing, -0.162 (union), -0.259 (nonunion); nonmanufacturing, -0.164 (union) and -0.328 (nonunion); percentage deviation of the fifth quintile from the median: manufacturing, 0.136 (union) and 0.267 (nonunion); nonmanufacturing, 0.162 (union) and 0.325 (nonunion).
} 
Table 1. Comparison of the Standard Deviation of the Log of Usual Hourly and Weekly Earnings Among Blue-collar Private Wage and Salary Male Workers, 1973-75, by Union Membership.

\begin{tabular}{|c|c|c|c|}
\hline \multirow[b]{2}{*}{ Sector } & \multirow[b]{2}{*}{$\begin{array}{l}\text { Number of } \\
\text { Observations }\end{array}$} & \multicolumn{2}{|c|}{ Standard Deviation of Log Eamings } \\
\hline & & $\begin{array}{c}\text { Usual } \\
\text { Hourly } \\
\text { Earnings }\end{array}$ & $\begin{array}{c}\text { Usual } \\
\text { Weekly } \\
\text { Earnings }\end{array}$ \\
\hline \multicolumn{4}{|l|}{ Manufacturing } \\
\hline Union & 8339 & .288 & .302 \\
\hline Nonunion & 6835 & .398 & .436 \\
\hline Difference & - & -.110 & -.134 \\
\hline $\begin{array}{l}F \text { test of dif- } \\
\text { ference in } \sigma\end{array}$ & - & 1.91 & 2.08 \\
\hline \multicolumn{4}{|c|}{ Nonmanufacturing } \\
\hline Union & 6253 & .950 & .366 \\
\hline Nonunion & 9227 & .451 & .508 \\
\hline Difference & - & -.101 & -.142 \\
\hline $\begin{array}{l}F \text { test of dif- } \\
\text { ference in } \sigma\end{array}$ & - & 1.66 & 1.93 \\
\hline
\end{tabular}

Source: Tabulated from May 1973, 1974, and 1975 Current Population Survey data tapes. Usual hourly eamings obtained by division of usual weekly earnings by usual hours worked. To eliminate effect of inflation on wage differences among the 3 years, the wages of 1974 were divided by 1.0765 ; those in 1975 by 1.1782 to put them on a 1973 basis, using average hourly earnings of workers on private payrolls [U.S. Department of Labor, Bureau of Labor Statistics, Employment and Training Report of the President (Washington, D.C.: G.P.O., 1977) Table C-3, p. 296]. Students and persons working fewer than 20 hours per week were deleted from the samples, and samples were limited to private wage and salary workers.

As a first step toward determining whether the markedly lower dispersion of earnings in the union sector can be attributed to union wage policies as opposed to the possibly greater similarity of union than nonunion workers, the standard deviation of the log of hourly earnings was calculated within more narrowly defined industry, occupation, geographic, education, and age groups. Table 2 summarizes the results in terms of the differences in the standard deviations $\left(\sigma_{u}-\sigma_{n u}\right)$ and the number of differences that are statistically significant at the 5 percent level. The data show clearly that inequality is smaller in the union sector within detailed categories. In manufacturing, the dispersion is lower among organized workers in all two-digit industries, in 68 of 75 three-digit industries, in all but 2 state groupings, and in all other categories.

Figure 1. Comparison of the Distribution of Hourly Earnings Among Union and Nonunion Male Blue-Collar Workers by Sector.

Manufacturing Sector

3

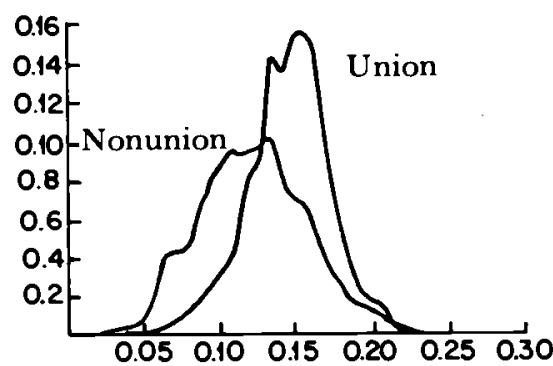

Log (Hourly Pay)
Nonmanufacturing Sector

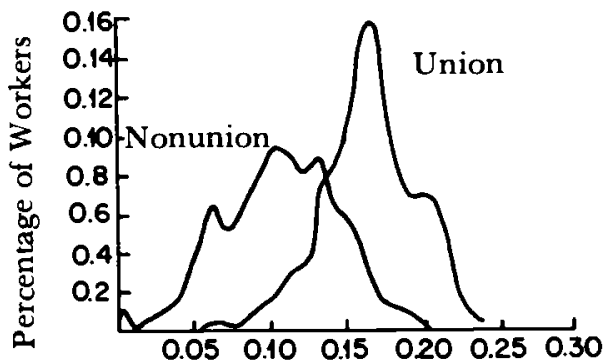

Log (Hourly Pay) 
Table 2. Differences in the Standard Deviation of the Log of Usual Hourly Earnings of Male Blue-Collar Workers by Selected Characteristics.

\begin{tabular}{|c|c|c|c|c|c|c|c|}
\hline Detailed Groups & $\begin{array}{c}\text { Total } \\
\text { Number } \\
\text { of } \\
\text { Groups }\end{array}$ & & $\begin{array}{l}\text { Distribu } \\
\text { (u non }\end{array}$ & $\begin{array}{l}\text { tion of Di } \\
\text { inion - }\end{array}$ & $\begin{array}{l}\text { fferences } \\
\text { union) }\end{array}$ & & $\begin{array}{c}\text { Number of } \\
\text { Differences } \\
\text { Statistically } \\
\text { Significant at } \\
5 \% \text { level or } \\
\text { better by } \\
\text { F test }\end{array}$ \\
\hline Manufacturing & & $>.00$ & $.00-.05$ & $.05-.10$ & $.11-.15$ & $<.15$ & \\
\hline $\begin{array}{l}\text { Two-digit } \\
\text { industry }\end{array}$ & 22 & 0 & 6 & 7 & 6 & 3 & 16 \\
\hline $\begin{array}{l}\text { Three-digit } \\
\text { industry }\end{array}$ & 75 & 7 & 14 & 20 & 18 & 15 & 50 \\
\hline $\begin{array}{l}\text { "Two-digit" } \\
\text { occupation }\end{array}$ & 16 & 0 & 5 & 9 & 2 & 0 & 13 \\
\hline State groups & 28 & 2 & 3 & 10 & 10 & 3 & 22 \\
\hline $\begin{array}{l}\text { Schooling } \\
\text { categories }\end{array}$ & 6 & 0 & 1 & 2 & 2 & 1 & 6 \\
\hline $\begin{array}{l}\text { Age } \\
\text { categories }\end{array}$ & 5 & 0 & 1 & 1 & 3 & 0 & 5 \\
\hline $\begin{array}{l}\text { SMSA-size } \\
\text { categories }\end{array}$ & 5 & $\mathbf{0}$ & 0 & 1 & 4 & 0 & 5 \\
\hline \multicolumn{8}{|l|}{ Nonmanufacturing } \\
\hline $\begin{array}{l}\text { Two-digit } \\
\text { industry }\end{array}$ & 22 & 3 & 3 & 4 & 7 & 4 & 12 \\
\hline $\begin{array}{l}\text { Three-digit } \\
\text { industry }\end{array}$ & 84 & 16 & 10 & 22 & 15 & 21 & 31 \\
\hline $\begin{array}{l}\text { "Two-digit" } \\
\text { occupation }\end{array}$ & 19 & 2 & 2 & 7 & 6 & 2 & 15 \\
\hline State groups & 29 & $\mathbf{0}$ & 3 & 11 & 10 & 5 & 25 \\
\hline $\begin{array}{l}\text { Schooling } \\
\text { categories }\end{array}$ & 6 & 0 & 0 & 5 & 1 & 0 & 6 \\
\hline Age categories & 5 & $\mathbf{0}$ & 1 & 2 & 1 & 1 & 5 \\
\hline $\begin{array}{l}\text { SMSA-size } \\
\text { categories }\end{array}$ & 5 & 0 & 0 & 3 & 2 & 0 & 5 \\
\hline
\end{tabular}

Source: Calculated from Current Population Survey tapes, May 1973 - May 1975.

In most of these cases, moreover, the differential is significant at the 5 percent level by the $F$ test, whereas in no case where $\sigma_{u}>$ $o_{n u}$ is the differential significant or large.

In the nonmanufacturing sector the pattern is less striking but still clear-cut. Among three-digit industries, $\sigma_{u}$ is less than $o_{n u}$ in 68 of 84 cases; it is significantly lower in 31 cases and not significantly higher in any. It is also lower by significant amounts in most of the other comparisons. On the basis of these comparisons, it appears that the lower dispersion of earnings among union workers cannot be attributed to such patterns as, say, a greater concentration of organized workers in certain industries, occupations, or age groups.

The effect of several characteristics on dispersion is estimated next by regressing the log of hourly and weekly earnings of union and nonunion workers, taken sep- 
arately, on years of schooling, experience (which is calculated as age - years of schooling - 5), experience squared, race, marital status and number of dependents, and dummy variables for geographic locale (state, SMSA), industry, and occupation. The equations provide estimates of the $b^{u}$ and $b^{n}$ coefficients needed for the various standardizations in Equations 3 and 4 and provide estimates of residual variances as well.

Table 3 presents the results of the regressions. Columns 1 and 2 record the mean and standard deviation of selected variables for union and nonunion workers and list the other control variables. The remaining columns give regression coefficients on four major determinants of earnings and other information about the calculations.

According to the standardization hypothesis, the regression coefficients on the principal wage-determining variables should be lower in the union sector. This expectation is borne out in the data. Lines 1-3 show noticeably smaller effects for schooling and experience in the union than nonunion equations. Given the small standard errors, the differences are highly significant. For example, in the fifth and sixth columns of coefficients, where an extensive set of control variables are used, schooling has a .034 impact on the hourly earnings of nonunion workers compared to .020 on the hourly earnings of union workers in manufacturing and a comparable differential effect of .028 versus .015 in the nonmanufacturing sector. The experience differentials are also markedly lower among union workers, suggesting flatter life cycle earnings profiles. The exclusion of union-negotiated fringe benefits, which accrue largely to older workers, ${ }^{18}$ however, leaves open the impact on total compensation, as opposed to straight-time pay. Only the coefficient on race shows any divergence from this pattern, with a smaller impact in the union equation in manufacturing but not in nonmanufacturing, a result possibly due to the

\footnotetext{
${ }^{18}$ Richard B. Freeman, "The Effect of Trade Unions on Fringe Benefits," NBER Working Paper No. 292 (Cambridge, Mass.: National Bureau of Economic Research, October 1978).
}

historic pattern of discrimination by craft unions.

The coefficients on the diverse dummy control variables listed in line 5 of the table can be compared in terms of a measure not shown in the table: the standard deviations of these coefficients for the union and nonunion groups. In manufacturing, the standard deviation of the estimated coefficients of the dummy variables among the 21 industry dummies used in columns 1.4 was 0.51 in the union sector compared to 0.55 in the nonunion sector. The equivalent standard deviations among occupations were 0.28 (union) and 0.33 (nonunion); among regions 0.08 (union) and 0.10 (nonunion); and among SMSA groups, 0.07 (union) and 0.08 (nonunion). Thus in each case the dummy variables reveal greater differentiation in the nonunion sector. In nonmanufacturing, the results are stronger: the standard deviation of coefficients on the dummy variables on 2-digit industry dummies is 0.56 for union and 0.92 for nonunion workers; the standard deviation on the coefficients for regions is 0.07 (union) versus 0.09 (nonunion); while the standard deviation on the coefficients by occupations are 0.51 (union) and 0.56 (nonunion). Comparable calculations based on the regressions with the more detailed controls in columns 7-10 give similar results. With states rather than regions as independent variables, the standard deviations of the dummy variable coefficients on geographic areas are: manufacturing, union (0.39), nonunion (0.57); nonmanufacturing, union $(0.29)$, nonunion (0.57). By contrast, the standard deviations of coefficients on the three-digit industry dummies are smaller than those at the two-digit industry level. ${ }^{19}$ Overall, the evidence suggests a diminution of the effect of the diverse wage-determining factors in the union sector, as predicted by the standardization policy.

To what extent is the lower standard

\footnotetext{
${ }^{19}$ With the same detailed controls the standard deviation of the dummy variable coefficients among industries were: manufacturing, 0.91 (union) and 0.94 (nonunion); nonmanufacturing, 2.11 (union) and 2.14 (nonunion), suggesting smaller differences as we further develop the industry variables.
} 


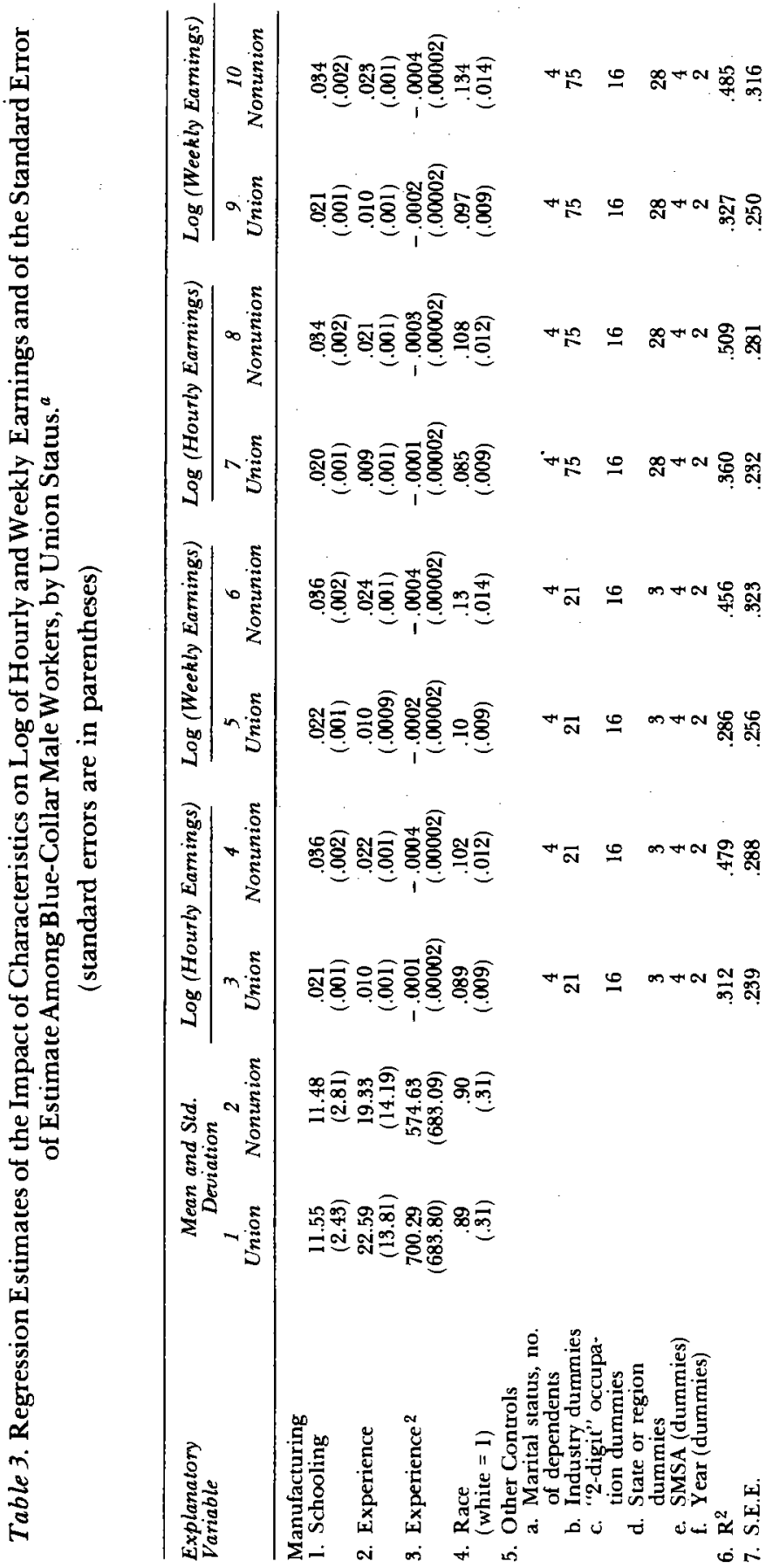




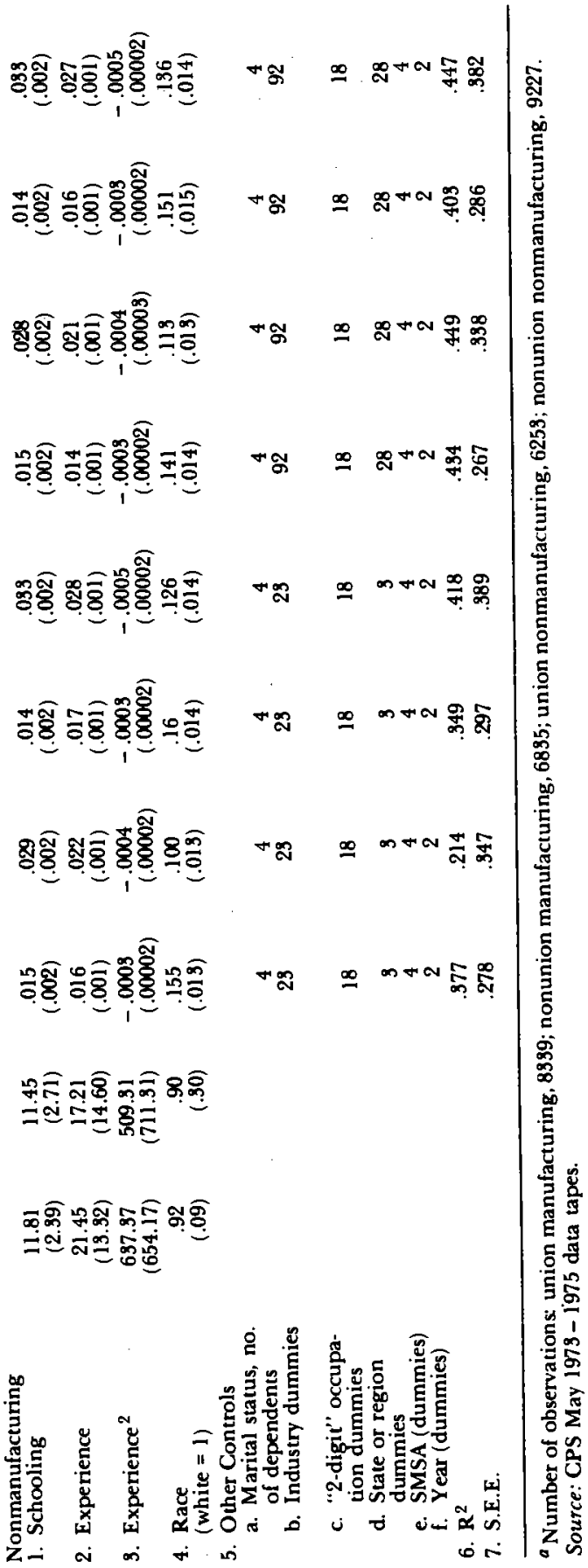


deviation of earnings in the union sector due to the reduction in the coefficients on wage-determining factors as opposed to differences in the variation of characteristics among workers? How much of the difference in dispersion is due to reduction in dispersion among workers with similar characteristics?

Calculations designed to answer these important questions are given in Table 4, which uses Equations 2 and 3 to evaluate the differential impact of the forces at work. Line 1 gives the differences in the standard deviation of the log of hourly earnings between union and nonunion workers. Line 2 estimates the difference that could result if union (nonunion) workers had the characteristics of nonunion (union) workers. Because workers in the union sample evince, in general, less dispersed characteristics, the figures in line 2 show a diminished differential in dispersion, though one that is not large enough to alter substantially the basic finding. According to the estimates, if union workers had the same dispersion of characteristics as nonunion workers, the variance of their wages would be substantially lower than the variance of the wages of nonunion workers. Adjustment for differences in characteristics has only a "moderate" effect on the differences in dispersion.

Line 3 of the table calculates the effect of the difference in regression coefficients on dispersion, using the characteristics of union and nonunion workers as weights. It shows that because of the smaller impact of measured factors on union than nonunion earnings, dispersion was lower by 0.050 to 0.078 points in manufacturing and by 0.041 to 0.044 points in nonmanufacturing. Finally, line 4 of the table compares the residual variation in the union and nonunion wage equations, as given by the standard errors of estimate at the bottom of Table 3. The standard errors of estimate from the regressions show that the union sector has less dispersion in both manufacturing and nonmanufacturing. Comparing the differences in dispersion due to the smaller regression coefficients in line 3 with the differences due to smaller residual variation in line 4 reveals an interesting difference between the manufacturing and nonmanu- facturing sectors. According to the table, unionism lowers dispersion in manufacturing largely by reducing the effect of measured characteristics while it lowers dispersion in nonmanufacturing largely by reducing variation within narrowly defined groups. What is important, however, is not the precise route of the impact but the fact that, corrected for differences in characteristics, union workers have a markedly lower dispersion of wages than nonunion workers.

Expenditures for Employee Compensation data set. The effect of unionism on dispersion can also be examined with establishment data on the compensation of production workers from the Expenditures for Employee Compensation (EEC) survey of the Bureau of Labor Statistics. The establishment data have both advantages and disadvantages for examining the standardization hypothesis. On the plus side, the data relate to total compensation (including fringes), giving a more comprehensive measure of compensation than earnings on the CPS tapes. In addition, unionization is measured by a $0-1$ collective bargaining coverage variable, which is 1 if 50 percent or more of the production workers are organized and 0 otherwise. This is presumably better than the union membership variable on the CPS, since wages are set by contracts for nonunion as well as union workers in the unit. One major disadvantage of the EEC tape is that the data do not contain information on worker characteristics and are limited to establishment averages for all production or nonproduction workers. To rectify the lack of information on personal characteristics, the mean education, percent above fifty and below thirty years of age, percent male, and percent black of union or nonunion production workers in the threedigit industry in which the establishment was located were added to the data tape, using estimates based on the CPS files. Detailed industry dummy variables and these measures partly remedy the lack of information on personal characteristics. Another problem, for which there is no remedy, is that for reasons of confidentiality the BLS deleted certain large establishments from the data set, with unclear effects on dis- 
Table 4. Estimates of the Effect of Differences in the Dispersion of Characteristics, of Differences in Regression Coefficients, and Residual Variation on the Difference in theStandard Deviation of the ln of Hourly Earnings Between Nonunion and Union Production Workers.

\section{Differences in}

Manufacturing

.110

.070

.088

.084

.082

b. Using nonunion wage equation

3. Difference attributable to different earnings equations

a. Using characteristics of union workers as weights

b. Using characteristics of nonunion workers as weights

4. Difference attributable to differences in residual variation

.049

.069

Source: Calculated from Current Population Survey tapes, May 1973- 75.

Line 1 from Table 1.

Line 2a: Estimated as $\sigma\left(W^{n}\right)-\hat{\sigma}\left(W^{u}\right)$ where $\hat{\sigma}\left(W^{u}\right)$ is calculated from $\hat{\sigma}^{2}\left(W^{u}\right)=\sum_{i}\left(\hat{b}_{i}^{u}\right)^{2} \sigma^{2}\left(X_{i}^{n}\right)+\sum_{i} \sum_{j} \hat{b}_{i}^{u} \hat{b}_{j}^{u} \sigma\left(X_{i}^{n} X_{j}^{n}\right) \quad$ (the variance that would be found among workers with the characteristics of nonunion workers paid by the union wage equation.)

Line 2b: Estimated as $\hat{\sigma}\left(W^{n}\right)-\sigma\left(W^{u}\right)$ where $\hat{\sigma}\left(W^{n}\right)$ is calculated from $\hat{\sigma}^{2}\left(W^{n}\right)=\sum_{i}\left(\hat{b}_{i}^{n}\right) \sigma^{2}\left(X_{i}^{u}\right)+\sum_{i} \sum_{j} \hat{b}_{i}^{n} \hat{b}_{i}^{n} \sigma\left(X_{i}^{u} X_{j}^{u}\right) \quad$ (the variance that would be found among workers with the characteristics of union workers paid by the nonunion wage equation.)

Line 3a: Estimated using Equation 3 with $\sigma^{2}\left(X_{i}^{u}\right)$ and $\sigma\left(X_{i}^{u} X_{j}^{u}\right)$ as weights.

Line $3 \mathrm{~b}$ : Estimated using Equation 3 with $\sigma^{2}\left(X_{i}^{n}\right)$ and $\sigma\left(X_{i}^{n} X_{j}^{n}\right)$ as weights.

Line 4: Calculated from columns 3 and 4 of Table 3, line 7.

persion. ${ }^{20}$

To obtain as large a sample as possible, the EEC surveys for 1967 - 68, 1969 - 70, and 1971 - 72 were amalgamated into a single sample. Despite its problems, the EEC survey is an especially valuable source of data on the impact of collective organization on dispersion because it permits us to check on one of the presumed routes of the standardization of wages, equalization of rates across establishments, which cannot be studied with data tapes on individuals.

Estimates of the link of trade unionism to

20See Richard B. Freeman and James L. Medoff, "New Estimates of Private Sector Unionism in the United States," Industrial and Labor Relations Review, Vol. 32, No. 2 (January 1979) for discussion of this problem. the standard deviation of the log of total hourly compensation for production workers in manufacturing industries in the EEC data file are given in Table 5. Line 1 records the number of union and nonunion establishments in the sample. Line 2 gives the standard deviations in the log of total compensation while line 3 records the standard error of estimate obtained by regressing the $\log$ of compensation on the variables listed in line 4 . Line 5 gives the $\mathrm{R}^{2}$ from the regression and line 6 compares standard deviations within specified narrow categories.

The principal conclusion to be drawn from the table is that, consistent with the standardization hypothesis, unionism is associated with markedly lower variations in compensation across establishments. 
Table 5. Estimates of Dispersion of Total Compensation Per Manhour of Nonoffice Workers Among Manufacturing Establishments, by Union Status.

\begin{tabular}{|c|c|c|}
\hline & Union & Nonunion \\
\hline 1. Number of observations & 2580 & 1494 \\
\hline $\begin{array}{l}\text { 2. Standard deviation of log of total } \\
\text { compensation per manhour }\end{array}$ & .258 & .302 \\
\hline $\begin{array}{l}\text { 3. Standard error of estimates of equation, } \\
\text { after regression on control variables }\end{array}$ & .194 & .221 \\
\hline \multicolumn{3}{|l|}{ 4. Regression variables } \\
\hline 20 industry dummies & $\checkmark$ & $\checkmark$ \\
\hline 5 year dummies & $\checkmark$ & $\checkmark$ \\
\hline 3 region dummies & $\checkmark$ & $\checkmark$ \\
\hline SMSA dummy & $\checkmark$ & $\checkmark$ \\
\hline Size of establishment & $\checkmark$ & $\checkmark$ \\
\hline $\begin{array}{l}\text { Characteristics of workers in } 3 \text { digit sector } \\
\text { (age, education, sex, race) }\end{array}$ & $\checkmark$ & $\checkmark$ \\
\hline Ratio production/nonproduction workers & $\checkmark$ & $\checkmark$ \\
\hline 5. $\mathbf{R}^{2}$ & .442 & .476 \\
\hline \multicolumn{3}{|l|}{$\begin{array}{l}\text { 6. Number of cases in which standard deviations } \\
\text { in groupings are smaller by statistically significant } \\
\text { amounts ( } 5 \% \text { level) by group }\end{array}$} \\
\hline a. Within 21 industries & 8 & 1 \\
\hline b. Within 9 size of establishment groupings & 6 & 0 \\
\hline c. Within 4 regions & 3 & 1 \\
\hline
\end{tabular}

\footnotetext{
${ }^{a}$ Characteristics of workers in 3 digit sector were obtained by taking the averages of the characteristics of bluecollar union and nonunion workers separately in each three digit industry from the May 1973 - 1975 Current Population Survey tapes.

Source: Expenditures for Employee Compensation data tapes, 1967 - 72.
}

The "raw" differences in standard deviations in line 2 differ by 0.044 or 15 percent, yielding an $\mathbf{F}$ statistic of 1.37, significant at better than one percent. The residuals from the regression differ by 0.033 , also 15 percent, and have an F statistic of 1.30 , also significant at better than one percent. The detailed comparisons in line 6 reveal significantly lower dispersions among union firms in eight of twenty-one industries compared to a significantly higher dispersion in just one industry; and significantly lower dispersions in the union sector in six of nine size categories and three of four regions.

The results in nonmanufacturing, summarized in Table 6, tell a more complex story, in part because of the peculiar distribution of firms among sectors. In the EEC union sample 54 percent of firms are in contract construction compared to 24 percent of nonunion firms. Given this differential pattern and the high wages in construction, the standard deviation of the log of hourly compensation turns out to be higher in the union sector (line 1), by a modest but statistically significant amount, contrary to our hypothesis. This result appears, however, to be due entirely to the sample differences noted above: when we look within industries, the results are reversed. This is clear in the regression of the log of hourly compensation on the industry controls and other variables. Because of the "peculiar" cross-industry distribution of establishments, the regression equation accounts for 71 percent of the variance in the log of earnings in the union sector (largely via the industry dummies) compared to 48 percent of the variance in the nonunion sector. "Corrected" for differences in characteristics, the direction of the difference in standard deviation is reversed. In line 3 , the residual dispersion of wages in the union sector is a sizeable 0.062 or 22 percent less than the residual dispersion in the nonunion sector. Although not shown, the F statistic between the variances is 1.63 , which is considerably larger than the $F$ of 1.11 in 
Table 6. Estimates of Dispersion of Total Compensation Per Manhour of Nonoffice Workers Among Nonmanufacturing Establishments, by Union Status.

\begin{tabular}{|c|c|c|}
\hline & Union & Nonunion \\
\hline 1. Number of Observations & 2393 & 3621 \\
\hline 2. Uncorrected for industry and other controls & .416 & .394 \\
\hline 3. Corrected for industry and other controls & .224 & .286 \\
\hline \multicolumn{3}{|l|}{$\begin{array}{l}\text { 4. Number of cases in which standard deviations } \\
\text { within groupings are smaller by statistically } \\
\text { significant amounts (5\% level) within industries } \\
\text { (number of establishments in parentheses) }\end{array}$} \\
\hline $\begin{array}{l}\text { a. Contract Construction } \\
\text { (1295 union, } 865 \text { nonunion) }\end{array}$ & .240 & .291 \\
\hline $\begin{array}{l}\text { b. Communication } \\
\text { ( } 40 \text { union, } 11 \text { nonunion) }\end{array}$ & .173 & .277 \\
\hline $\begin{array}{l}\text { c. Electricity, Gas and Sanitary Service } \\
\text { ( } 109 \text { union, } 4 \text { I nonunion) }\end{array}$ & .134 & .704 \\
\hline $\begin{array}{l}\text { d. Wholesale Trade } \\
\text { (129 union, } 383 \text { nonunion) }\end{array}$ & .289 & .361 \\
\hline $\begin{array}{l}\text { e. Banking, Credit and Security Services } \\
\text { ( } 2 \text { union, } 96 \text { nonunion) }\end{array}$ & .149 & .401 \\
\hline $\begin{array}{l}\text { f. Rooming, Personnel and Miscellaneous Services } \\
\text { (214 union, } 495 \text { nonunion) }\end{array}$ & .290 & .353 \\
\hline $\begin{array}{l}\text { g. Amusement and Recreation } \\
\text { (9 union, } 49 \text { nonunion) }\end{array}$ & .683 & .394 \\
\hline $\begin{array}{l}\text { h. Educational } \\
\text { (10 union, } 75 \text { nonunion) }\end{array}$ & .130 & .350 \\
\hline
\end{tabular}

Source: Expenditures for Employee Compensation data tapes, 1967 - 1972.

line 1. More importantly, comparisons of standard deviations within 27 industry groupings in line 4 show seven with significantly lower dispersions among union plants compared to one with significantly higher dispersion in the union sector. Thus, although somewhat more equivocal due to a greater raw standard deviation for the union sample, the EEC data on nonmanufacturing tend to support the conclusion that dispersion is lower in the union sector.

\section{Impact on White-Collar/Blue-Collar Differences}

Thus far we have found that dispersion of wages among organized blue-collar workers is lower than dispersion of wages among unorganized blue-collar workers for two reasons: smaller impacts of wage-determining factors on earnings and smaller "residual variation" among similar workers. Since we included occupation and skill variables in our analysis and found smaller coefficients on those variables, we have dealt with the impact of unionism on bluecollar skill differences as well as on the union effect on workers within skill categories.

There is, however, one important effect of unionism on within-establishment inequality that has been ignored in our analysis, namely, the effect of union wage gains on the white-collar/blue-collar differential. Since unionization occurs almost exclusively among blue-collar workers and since white-collar workers tend to be paid more, on average, than blue-collar workers, the union wage effect tends to reduce inequality in this case.

The magnitude of the impact of trade unionism on the white-collar/blue-collar differential within the union sector can be estimated by regression analysis using the EEC data set. Let $W=$ wage of blue-collar workers; $\boldsymbol{X}=$ characteristics of blue-collar workers; $U N=0-1$ dummy variable for 
Table 7. Estimates of the Impact of Unionism on the Office Worker (White-Collar)/ Nonoffice Worker (Blue-Collar) Differential in Total Compensation Per Manhour, by Sector. ${ }^{a}$

\begin{tabular}{lcc}
\hline & Manufacturing & Nonmanufacturing \\
\hline 1. Number of establishments & 4074 & 6014 \\
2. Mean differential (standard deviation) & $.397(.356)$ & $.266(.506)$ \\
3. Regression coefficient (standard error) & & \\
on union dummy variable & $-.12(.018)$ & $-.14(.024)$ \\
4. Additional controls & & \\
a. Age dummies, blue-collar & 2 & $\checkmark$ \\
b. Percent male, blue-collar & $\checkmark$ & $\checkmark$ \\
c. Mean education, blue-collar & $\checkmark$ & $\checkmark$ \\
d. Percent white, blue-collar & $\checkmark$ & 2 \\
e. Age dummies, white-collar & 2 & $\checkmark$ \\
f. Percent male, white-collar & $\checkmark$ & $\checkmark$ \\
g. Mean education, white-collar & $\checkmark$ & $\checkmark$ \\
h. Percent white, white-collar & $\checkmark$ & 3 \\
i. Region dummies & 3 & 29 \\
j. Industry dummies & 20 & $\checkmark$ \\
k. Ratio white- to blue-collar workers & $\checkmark$ & $\checkmark$ \\
l. Number of workers & $\checkmark$ & .251 \\
5. R & .152 & .440 \\
6. S.E.E. & .329 &
\end{tabular}

a The dependent variable is in (total compensation per manhour of office workers/total compensation per manhour of nonoffice workers).

Source: Expenditures for Employee Compensation data tapes, 1967 - 72.

collective bargaining coverage of bluecollar workers; $W_{w}=$ wage of white-collar workers; and $\boldsymbol{X}_{\boldsymbol{w}}$ characteristics of whitecollar workers. Then the following regression model can be used to estimate the change in the differential within an establishment due to unionism:

$$
\begin{gathered}
\ln \left(W_{w} / W\right)_{\mathrm{i}}=a_{0} \\
+a_{1} X_{w i}-a_{2} X_{i}-a_{3} U N_{i}+\varepsilon_{i}
\end{gathered}
$$

where $\varepsilon$ is a random variable with mean 0 and variance $\sigma^{2}$. The distinctive feature of Equation 5 is that it exploits the existence of data on blue- and white-collar workers within the establishment to determine the effect of unionism on intra-establishment inequality. Because the dependent variable refers to within-establishment differences, any "omitted firm factor" that affects both blue- and white-collar workers has similarly been differenced away in the calculation. The coefficient on unionism reflects the impact of collective bargaining on bluecollar wages relative to its (positive, nega- tive, or zero) "spillover" effect on whitecollar wages.

Table 7 presents estimates of Equation 5 with the following set of control variables: region and SMSA and industry dummies comparable to those in Table 3 , the mean characteristics of white- and blue-collar workers in the organized and unorganized three-digit industry on which the establishment is located (from the May CPS tapes, as described earlier); unionism of blue- and white-collar workers; and the ratio of whiteto blue-collar workers in the establishment. Line 1 of the table records the number of establishments in the analysis; line 2 gives the average white-collar premium in the establishments; line 3 gives the coefficient on the collective bargaining coverage dummy variable; line 4 gives the additional controls in the experiment while the remaining lines give the summary statistics.

The calculations show that the whitecollar/blue-collar differential is significantly reduced by collective bargaining of 
blue-collar workers in both manufacturing and nonmanufacturing industries. In manufacturing an average differential of .40 (line 2) is reduced by .12 points as a result of collective bargaining of plant workers. In nonmanufacturing, an average differential of .27 is reduced by .14 points. By lowering the income advantage of white-collar workers in an establishment, trade union wage gains reduce inequality in the organized sector.

\section{Total Effects of Unionism on Wage Dispersion}

Given the preceding estimates of the impact of trade unionism on the dispersion of wages among organized blue-collar workers and on the white-collar/blue-collar differential, what is the total effect of unionism on dispersion in the organized sector? And how does this effect compare to possible increases in dispersion due to the union/nonunion blue-collar wage differential?

The impact of unionism on the dispersion of wages in the organized sector as a whole can be evaluated by the standard conditional variance formula. Let $\boldsymbol{\sigma}_{s}^{2}$ be the variance in In wages for all workers in a sector and $\boldsymbol{\sigma}_{b}^{2}$ be the variance for production (blue-collar) workers and $\sigma_{w}^{2}$ the variance for white-collar workers and let $\alpha$ be the production (blue-collar) worker share of workers. Then if $\left(\bar{W}_{w}-W_{b}\right)$ is the differential between the mean ln wages of whitecollar and blue-collar workers,

$$
\begin{gathered}
\sigma_{s}^{2}=\alpha \sigma_{b}^{2}+(1-\alpha) \sigma_{w}^{2} \\
+\alpha(1-\alpha)\left(\bar{W}_{w}-\bar{W}_{b}\right)^{2} .
\end{gathered}
$$

Table 8 presents estimates of the total effect of trade unionism on inequality in the organized sector, using Equation 6. Line 1 records the standard deviation in the log hourly earnings of production workers with the nonunion dispersion of characteristics from Table 1 and the estimated dispersion of In hourly earnings if those workers were organized, using the estimates in Table 4. Line 2 records the contribution of the standard deviations to the variance in ln earnings using Equation 6, with $\alpha$ estimated as described in the table note. ${ }^{21}$ The next two

${ }^{21}$ Evidence given in Richard B. Freeman and James L. Medoff, "Substitution Between Production Labor lines estimate the contribution of the whitecollar/blue-collar differential to the dispersion. The estimate of the differential in the absence of unionism is the actual in differential between male white-collar and blue-collar workers on the CPS file, uncorrected for any differences in characteristics on the assumption that these are, in fact, different forms of productive labor. The estimate of the differential in the presence of unionism is obtained by deducting the estimated effect of unionism on the differential, using the regressions in Table 7.22 The contribution of the differential to the variance is estimated as $\boldsymbol{\alpha}(1-\boldsymbol{\alpha})\left(\bar{W}_{w}-\bar{W}_{b}\right)^{2}$ according to Equation 6 . Line 5 records estimates of the standard deviation of the hourly earnings of white-collar workers, using data from the May 1973 - 75 CPS file. In this calculation we assume that the variance of earnings among white-collar workers is the same in the nonunion and union sectors and can be approximated by the dispersion among all white-collar workers. ${ }^{23}$ If there is a spillover of union standardization policies on white-collar labor, we have underestimated the overall impact of unions

and Other Inputs in Unionized and Nonunionized Manufacturing," Review of Economics and Siatistics (forthcoming), Table 2, shows that the division of production and nonproduction workers differs somewhat between the union and nonunion sectors in manufacturing in the EEC. In the union sector, production workers constitute 65 percent of total manhours; in nonunion manufacturing, production manhours constitute 72 percent. This difference is too small to merit analysis with different proportions.

${ }^{22}$ This is an approximation as the regression estimates relate to the effect of unionism on the mean in blue-collar/white-collar differential rather than to the difference between the mean in blue-collar wage and the mean In white-collar wage.

${ }^{23}$ While this assumption seems sufficiently plausible that any difference in dispersion of earnings among white-collar workers could be attributed to "other factors," it is important to make sure that there are no enormous disparities that would raise the overall dispersion in the union sector. Accordingly, I calculated the standard deviation of total compensation per manhour of office workers in the EEC sample, finding figures of 0.29 in union manufacturing. 0.40 in nonunion manufacturing, and 0.42 in union nonmanufacturing, and 0.46 in nonunion nonmanufacturing. Whatever interpretation is placed on these differences, they do not run counter to the assertion that overall dispersion is lower in the union sector. 


\section{Table 8. Estimated Effects of Unionism on Within-Sector Dispersion of Hourly Earnings.}

\begin{tabular}{|c|c|c|c|c|}
\hline \multirow{2}{*}{. } & \multicolumn{2}{|c|}{ Manufacturing } & \multicolumn{2}{|c|}{ Nonmanufacturing } \\
\hline & Nonunion & Union & Nonunion & Union \\
\hline $\begin{array}{l}\text { 1. Standard deviation of earnings, } \\
\text { male blue-collar workers }\end{array}$ & .398 & .810 & .451 & .369 \\
\hline $\begin{array}{l}\text { 2. Contribution of line } 1 \text { to } \\
\text { variance in } \ln \text { earnings } \\
(\alpha) \sigma^{2}\end{array}$ & .116 & .070 & .114 & .076 \\
\hline $\begin{array}{l}\text { 3. White-collar/blue-collar } \\
\text { differential }\end{array}$ & .46 & .34 & .37 & .23 \\
\hline $\begin{array}{l}\text { 4. Contribution of line } 3 \text { to } \\
\text { variance in earnings }[(\alpha)(1-\alpha) \times \\
\text { squared differential, line } 3]\end{array}$ & .042 & .023 & .034 & .018 \\
\hline $\begin{array}{l}\text { 5. Standard deviation of earnings, } \\
\text { male white-collar workers }\end{array}$ & .442 & .442 & .554 & .554 \\
\hline $\begin{array}{l}\text { 6. Contribution of line } 5 \text { to } \\
\text { variance in earnings }[(1-\alpha) \times \\
\text { square of line } 5]\end{array}$ & .086 & .086 & .136 & .136 \\
\hline $\begin{array}{l}\text { 7. Total variance of earnings } \\
\text { (lines } 2+4+6 \text { ) }\end{array}$ & .244 & .179 & .284 & .225 \\
\hline $\begin{array}{l}\text { 8. Standard deviation of earnings } \\
\text { (square root of line } 7 \text { ) }\end{array}$ & .494 & .423 & .533 & .474 \\
\hline
\end{tabular}

Sources: Line 1: figures for absence of unionism from Table 1 ; figures for presence of unionism obtained by subtracting estimated effect of unionism on comparable workers from Table 4 , line $2 b$.

Line 2: estimated $\alpha$, blue-collar share of male workers taken from CPS files: 0.73 for manufacturing and 0.56 for nonmanufacturing. Note that CPS estimates outside manufacturing differ from production worker figures in establishment surveys, in part because of different classifications and in part because of the large number of $\mathrm{fe}$ male blue-collar workers outside manufacturing.

Line 3: figure for absence of unionism obtained by taking In differential between usual weekly earnings/usual hours worked of all male white-collar workers and of nonunion blue-collar workers in the sample. Figure for presence of unionism obtained by deducting estimated union effect from Table 7, line 3.

Line 5: calculated from May 1973 - 75 CPS tapes, based on samples of 5568 manufacturing and 13,044 nonmanufacturing workers.

in lowering inequality. Line 6 uses Equation 6 to estimate the contribution of dispersion among white-collar workers to the total variance.

The payoff to the calculations is in the final lines of the table, which show the estimated variance and standard deviation of earnings in the absence of unionism and estimated variance and standard deviation of earnings in the presence of unionism. In both the manufacturing and nonmanufacturing sectors unionism is estimated to reduce dispersion significantly. Unionism lowers the standard deviation by .071 points or 14 percent in manufacturing, and by .059 points or 11 percent in nonmanufacturing; unionism lowers the variances by .065 points ( 27 percent) in manufacturing and by
.059 points ( 21 percent) in nonmanufacturing.

The final issue to consider is how the estimated dispersion-reducing effects of unionism compare to the dispersion-increasing effects of unionism due to the union wage effect. Are the dispersion-reducing or the dispersion-increasing effects of unionism larger? Calculations designed to answer this question are presented in Table 9 . It uses the conditional variance equation (Equation 6), applied to union and nonunion male bluecollar workers, to estimate the effect of unionism on the dispersion of wages of all male blue-collar workers and then considers the contribution to wage dispersion of the effect of unionism on the male white-collar/ blue-collar differential. Line 1 records esti- 
Table 9. Comparison of the Estimated Dispersion-Decreasing and Dispersion-Increasing Effects of Unions on the Earnings of Male Workers.

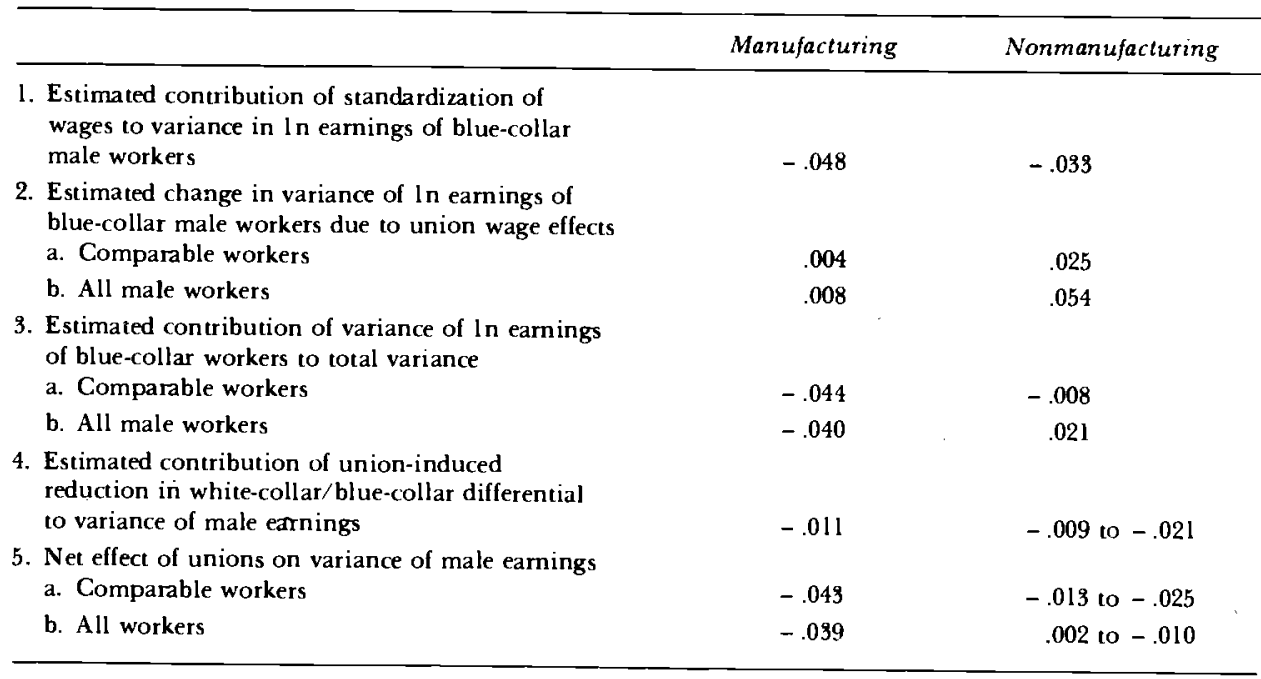

Source:

Line 1: Multiplicand of estimated reduction in variance from $\Gamma$ able 4 . line $2 \mathrm{~b}$ with union share of blue-collar male labor from Table 1. Union share in manufacturing $=0.55$; union share in nonmanufacturing $=0.40$.

Line 2a: Multiplicand of union share of blue-collar male workers, nonunion share, and the squa re of the estimated union wage effect, with wage effect of 0.12 in manufacturing and 0.32 in nonmanufacturing.

Line 2b: Multiplicand of union share of blue-collar male workers, nonunion share and the difference between the square of the estimated differential between union and nonunion workers in the presence of union ism and the square of the estimated differential between union and nonunion workers in the absence of unionism. The estimated differentials are 0.07 in manufacturing and 0.19 in noninanufacturing in the absence of unions; 0.19 in manufacturing and $0.5 \mathrm{l}$ in nonmanufacturing in the presence of unions.

Line 3: Sum of line 1 and lines $2 a$ or $2 b$.

Line 4: The differential in the presence of unionisnt is the actual differential on the CPS files: manufacturing 0.36, nonmanufacturing 0.26 . The differential in the absence of unions in manufacturing is 0.43 , the sum of 0.36 and the multiplicand of the estimated effect of unionism on the white-collar/blue-collar differential from Table 7 and the union share of blue-collar labor. The first estimated differential in the absence of unions in nonmanufacturing is 0.32 , the sum of 0.26 and the multiplicand of the estimated effect of unionism on the white-collar/blue-collar differential from Table 7 and the union share of blue-collar labor. The second estimated differential in the absence of unionism in nonmanufacturing is 0.39 , the sum of 0.26 and the multiplicand of the estimated union wage effect on the CPS file and the union share of labor.

Line 5: Sum of line 4 and blue-collar share of male workers multiplied by lines $3 \mathrm{a}$ or $3 \mathrm{~b}$.

mates of the effect of the reduced dispersion of wages among blue-collar workers, by sector. It is obtained by multiplying the estimated effect of unions on comparable workers (Table 4 , line $2 \mathrm{~b}$ ) by the proprotion of male blue-collar workers who are organized, as given in the figures in Table 1. Since roughly half of male workers are union members, the figure in line 1 is about half of the estimated effect of unions on the variance of blue-collar workers.

Line 2 presents two separate estimates of the dispersion-increasing effect of the union wage differential on the variance. Line $2 a$ records the effect of union wage gains on the dispersion among comparable workers, obtained by estimating the union wage effect in the CPS data. Controlling for all other characteristics included in Table 2, the union premium among male blue-collar workers was estimated to be 0.12 in manufacturing and 0.32 in nonmanufacturing. ${ }^{24}$

21 This analysis is based on a regression of log hourly earnings on all of the control variables listed in Table 3. In manufacturing, with the smaller set of controls, the union coefficient and standard error were 0.12 (.005), with the larger set of controls, the coefficient and standard error were 0.11 (.005). In nonmanufacturing the estimates were $0.32(.006)$ with smaller set of controls, and $0.311(.006)$ with larger set of controls. 
Following Equation 6, the premium is squared and multiplied by the relevant shares of union and nonunion workers among male blue-collar workers. Line $2 b$ uses the estimates of the union premium and the differential between union and nonunion blue-collar men, uncorrected for differences in characteristics, to evaluate the dispersion-increasing effect of unions on male blue-collar labor. The estimates in $2 \mathrm{~b}$ take account of the fact that unionized labor tends to be more skilled and therefore higher paid than nonunion labor, even in the absence of organization. The estimates are obtained in accordance with Equation 6 by subtracting the square of the differential between union and nonunion workers in the presence of unionism and the estimated differential in the absence of unionism. The difference in the presence of unionism is the "raw" uncorrected difference while the estimated differential in the absence of unionism is the raw differential minus the estimated union wage effect.

The results of these calculations are clear. Among manufacturing workers, the dispersion-reducing effects of unions dominate the dispersion-increasing effects, both among all blue-collar workers and among comparable blue-collar workers. Among nonmanufacturing workers, on the other hand, the net effects are small, with a slight reduction in dispersion in the comparable workers' calculation and an increase in the all workers' calculation.

Line 4 contains estimates of the change in the variance of earnings due to the impact of unionism on the white-collar/blue-collar differential. In both manufacturing and nonmanufacturing, the differential in the presence of unionism is taken to be the actual differential in the CPS files for the relevant sector. In manufacturing, the differential in the absence of unionism is estimated as the actual differential plus the multiplicand of the union share of blue-collar labor and the estimated effect of unions on the white-collar/blue-collar differential in Table 7 . In nonmanufacturing, due to the

There were 15,480 observations in nonmanufacturing and 15,174 in manufacturing. significant difference between the estimated effect of unionism on the white-collar/bluecollar differential in the EEC file (0.14) and the estimated union wage effect in the CPS file (0.32) (a pattern that is consistent only if unions have a major "spillover" effect on white-collar labor), two estimates are given. The first (lower) estimate uses the EEC estimates of the effect of unionism on the white-collar/blue-collar differential (multiplied by the union share of blue-collar labor) while the second estimate assumes that the differential is lowered by the CPS estimated union wage effect (multiplied by the union share of blue-collar labor). Because in manufacturing the estimated effect of unionism on the white-collar/blue-collar differential in the EEC file and the estimate of the union wage effect in the CPS file are of the same magnitude, only one estimate is necessary on that sector.

The final line gives our estimates of the impact of unions on dispersion of male workers in both sectors. In manufacturing, the effect is clearly negative and reasonably large. In nonmanufacturing, where the union share of employment is lower and the estimated union/nonunion wage differential larger, the direction of the effect is smaller and dependent on whether EEC or CPS estimates of the effect of unionism on white-collar/blue-collar differentials are used.

Finally, what about the effect of unionism on the manufacturing/nonmanufacturing differential? Focusing once more on production workers, the contribution of unionism to the differential wages in manufacturing versus nonmanufacturing can be estimated from the evidence on proportions of workers organized in the two sectors, the size of the union wage effect, and the basic differential between the sectors. Since unionism, by our estimates, raised the wages of 55 percent of male production workers in manufacturing by 0.12 points compared to an effect of 0.32 points on 40 percent of male production workers in nonmanufacturing, the overall wage of blue-collar manufacturing workers may have risen by 0.06 points compared to an increase of 0.13 points in nonmanufacturing. The differential between nonunion workers in the two 
sectors was 0.11 in favor of manufacturing workers. If, in fact, unions raised the earnings of nonmanufacturing workers by 0.07 points relative to manufacturing workers, the net effect would be to reduce inequality by lowering the manufacturing advantage from 0.11 to 0.04 , reducing dispersion by a modest amount, according to the relevant part of Equation 6.

In sum, the dominant effect of unionism on dispersion is through the reduction in intrasectoral dispersion, with the sizeable reduction in dispersion in manufacturing leading to an overall reduction in inequality. ${ }^{25}$

\section{Conclusions, Provisos, and Implications}

The major findings of this study can be summarized briefly as follows:

(1) Trade unions have adopted wage policies designed to reduce dispersion of earnings within and across establishments, for what can be rationalized as plausible economic reasons.

(2) Other things equal, the dispersion of earnings is significantly lower among organized blue-collar workers, in part because of a reduced effect of standard wage-determining factors on earnings and in part because of smaller dispersion within categories of workers having the same wage-determining characteristics.

(3) Dispersion of average compensation is also lower among establishments that are unionized than among those that are not.

(4) Unionism reduces white-collar/blue-

25 These calculations are, it should be stressed, consistent with Lewis's estimates of the enlarged dispersion of the interindustry wage structure due to unionism. According to Lewis (p. 292), unionism may have increased dispersion of wages among industries by 0.022 to 0.026 In points in 1958. Assuming a similar impact in the 1970 s, we see that the dispersion-reducing effects in line 1 of Table 9 exceed these figures. Note that Lewis's estimated 8 percent increase in dispersion (p. 295) takes as its base the dispersion of wages among industries, not the dispersion among people. It is thus appropriate to use his estimates of the In point effect of unions rather than of the percentage effect of union wage gains on dispersion. collar earnings differentials in the organized sector, further contributing to within-sector reductions in dispersion.

(5) Overall, the within-sector effect of unionism on dispersion appears to more than offset the increase in dispersion of earnings across industries, so that on net unionism reduces inequality.

The major weakness with these findings is that, despite our efforts, at least some of the lower dispersion in the union sector may be due to inadequately controlled characteristics of organized workers. While our controls have been at least as complete as those in other studies, the possibility that more narrow groupings would reduce the difference in variances cannot be denied. In addition, to minimize problems of comparability we have dealt exclusively with male workers, which leaves open the possibility that if (for some unknown reason) unionism has a different effect on the dispersion of wages of women, our results may not be generalizable. To the extent that reduction in dispersion of earnings leads to reduced dispersion of abilities in the union sector, there may be little or no economywide effect on inequality or efficiency.

Assuming that the result is correct, however, the welfare implication of a reduction in wage inequality due to unionism is by no means clear. To the extent that the dispersion of wages reflects disequilibrium, the influence of peculiar nonmarket forces, and the failure of the market to bring about "equal pay for equal work," the reduction in dispersion among comparable workers may have desirable efficiency implications. To the extent that the dispersion in the absence of unionism reflects dispersion of marginal products perfectly, however, the reduction among comparable workers may cause inefficiencies. Finally, of course, the distributional effects of standard wage policies must also be weighed in any assessment of their effect on welfare. Normative issues aside, what is important is that unions have a sizeable, generally neglected, impact on withinsector dispersion, which may be attributable to their standardization-of-rate policies. 